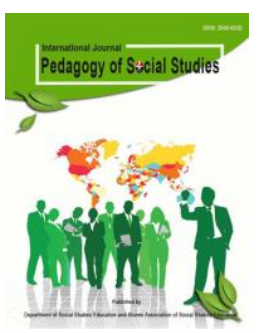

\author{
International Journal Pedagogy of Social Studies
}

p-ISSN : $2550-0600$

e-ISSN $\underline{2549-6530}$

\title{
"BRTT" (Clean, Neat, Orderly, Organized) Program as a Pioneer of Daarut Tauhid Santri with Ecological Intelligence
}

\author{
Dea Mutiara ${ }^{1}$, Mamat Ruhimat ${ }^{2}$, Yakub Malik ${ }^{3}$ \\ Social Science Study Program, Faculty of Social Science Education \\ Universitas Pendidikan Indonesia, Bandung, Indonesia
}

\begin{abstract}
Daarut Tauhid as one of the educational institutions that study religion proves that an islamic boarding school does not only deepen the Holy Qur'an and hadith; but also does real activities in the society. Researchers are interested in capturing the process of implementing the "BRTT" program to the ecological intelligence of the Santri ${ }^{1}$ of Daarut Tauhid. This research uses a qualitative approach with a case study method. The subjects of this study include the santri from Daarut Tauhid, the Quality Control Team and Daarut Tauhid Principal. The data are collected through observation, interviews, and documentation. The results of this study indicate that the background of implementing this program is the desire to make islamic boarding schools as pioneers of a clean, neat, orderly, and organized attitude to its santri and to the people who live nearby. The process of implementing the BRTT program is carried out in two categories: internally and externally. The obstacles encountered in the implementation of the BRTT program were self-habit constraints and fatigueness. The factors that influence the students in being disciplined in implementing BRTT are self-consciousness and environmental habit. The ecological intelligence of the students of Daarut Tauhid consists of seven aspects: (1) understanding environmental issues and problems from the perspective of ecological balance and sustainability, (2) conducting BRTT starting with a rule, mandatory policies which gradually become a habit and are inherent in self, (3) ways of solving problems creatively and applying knowledge in a new situation (ecological context), (4) oftenly assess the impact and the effects of human actions and technology on the environment, (5) oftenly take into account of the long-term consequences in taking a decisions (environmental context), (6) knowing indicators of clean and healthy living behavior, also (7) ways to give attention, empathy, and care for others and other living things.
\end{abstract}

Keywords: Program, Daarut Tauhid, Ecological Intelligence

Correspondence. deamutiara444@gmail.com

Article History. Received, Received in revised, Accepted

C2020. International Journal Pedagogy of Social Studies. Department of Social Studies Education

\section{A. INTRODUCTION}

One of the well-known islamic boarding school which is still in demand by many people is the Daarut Tauhid Boarding School. Daarut Tahuid is led by a Kiai Haji named Abdullah Gymnastiar. As with other Islamic boarding schools, the core activities at Daarut Tauhid is in the fields of education, da'wah \& social affairs. But, Daarut Tauhid has one unique distinct feature which is mandatory program for all of the people who live nearby whether they are mukim or santri students. The program was called BRTT (clean, neat, orderly, organized). "Santri mukim" is a regular santri who registers as a student to attend the boarding school. They usually live in the school until they have finished their education. Meanwhile, "santri karya" are the individuals who work for Daarut Tauhid.

BRTT is a combination of several concepts, namely clean, neat, orderly,

\footnotetext{
${ }^{1}$ Santri is the students of islamic boarding school
} 
organized. "BRTT" is a program that aims to instill a caring attitude towards oneself and the environment. For example: by not letting rubbish littered on the road is a real action of minimizing the existence of dirty, polluted and even environmental problems which can also cause natural disasters such as floods associated to low health due to environmental degradation. Neat, orderly and organized are forms of discipline. Developed countries are highly disciplined. Japan is one of the developed countries that upholds discipline habit. Individuals who hold to discipline will understand how to live according to the rules. One of them is by living in harmony with nature that will make our life more peaceful and safe.

The BRTT program (clean, neat, orderly, and organized) from Daarut Tauhid is conceptually excellent because with this program, every individual, especially students of the boarding school can have an understanding of ecological intelligence. Ecological intelligence is thoughts, attitudes and actions that are in the unity with nature, and every deeds that it has done, not only have an impact on humans but also have an impact on the lives of other living things.

Ecological intelligence according to Golemen in Supriatna (2016, p. 24) is to integrate cognitive skills with empathy for all forms of life. Social and emotional intelligence is built on the ability to see from the perspective of others, feel the conditions felt by others, and show our concern. Meanwhile, according to Supriatna (2016, p. 24) ecological intelligence is based on knowledge, awareness, and life skills that are in harmony with nature. Someone who has ecological intelligence will understand that every behavior not only affects himself and others, but also affects the environment in which he lives, which must be maintained so that he still has the carrying capacity for his and others' lives.

Daarut Tauhid as one of the educational institutions that study religion proves that pesantren do not always deepen the Qur'an and Hadith and, but also does real activities in society. Humans and the environment is a unity that can not be separated. This means that there is a balance that must be maintained for each other to the sake of their existence and survival. All elements of society, be it individuals, groups, the private sector, or the government have a responsibility in protecting the living ecosystem. Cleanliness of the environment will have an impact on health. According to Law No. 36 of 2009 concerning health, health is a healthy condition, both physically, mentally, spiritually and socially that allows everyone to live productively and economically (quoted from Health Law No. 36 of 2009, pg, 4). Salim (1982, hm, 1) explained that Indonesia since 1978 included environmental problems in Repelita III as an Integral part of the National Development Policy. The condition is described straight forwardly by Aris (2011) as follows: "Exploitation of natural resources and the environment is inevitable as a logical consequence of the paradigm of thinking of industrialism and developmentalism. The earth and the environment along with other creatures besides humans have lost their existence and essential rights in the framework of their ecology and ecosystem.

According to Azwar (1996, p. 20), the effect of environmental cleanliness on human health can be divided into two types, namely: first, the effects that occur are immediate. That is, once environmental factors that are not clean are present in human life, there arises disease. Second, the resulting effects occur gradually. That is, the presence of environmental factors that are less clean will lead to disease in long term period of time.

Muhaimin (in Septian. 2016, p. 5-6) stated that there are six indicators included in environmental knowledge, namely: 1) Knowledge of the causes of environmental problems, 2) Knowledge of the impact of environmental problems, 3) Knowledge of solutions to solving environmental problems,

4) Knowledge of predicted future environmental problems, 5) Knowledge of environmental problems in daily life, 6) Understanding of human-environmentally dependence as well as their dependence among individuals, communities and nations both in local and global contexts. In line with the opinion above, Orr (in Setiawati. 2016. p. 4) stated that "someone who is ecologicallysmart must have knowledge of the importance of understanding the 
interrelationships between one group and other components and being concerned about an occupation. It means someone who is ecologically literate knows how to relate and behave with their ecosystem

According to Capra (in Satria. 2016, p. 4) Four Competency Sets for Ecological Intelligence of observable natural practices in caring for the environment can be seen through the ability to protect the environment related to cleanliness (waste management) and the presence of plants or trees as health support environment, for example: making sure the waste is in its place, not producing excessive waste, increasing greenery (planting plants / trees), and caring for plants (watering, cleaning, loosening the soil, and observing its growth) routinely.

A research conducted by Sasmita in 2017, which examined the Adiwiyata-based of Madrasah policy as a means of developing Ecological Intelligence shows significant result which can be seen from the people's habits, their emphatic attitudes, their sense of caring and responsible to their surrounding environment and their own living space.

Based on the above explanations, the researchers are interested in capturing the implementation of BRTT Program through the Ecological Intelligence of Daarut Tauhid Santri.

\section{B. METHOD}

This study uses a qualitative approach with a case study method to determine the process of implementing the "BRTT" program to the ecological intelligence of Daarut Tauhid students. As for the selection of research subjects, the researchers are using the non-probability sampling method, which is a sampling technique that does not provide equal opportunities for each element or member of the population to be selected as a sample, with a purposive technique. Some of these subjects include students from Daarut Tauhid as the executor of the "BRTT" Program, the Quality Control Team as a supervisory team that works under the Internal Supervisory Unit (SPI) and the Boarding School Board Leaders who are considered to know more about the "BRTT" program.
Table 1. List of Key Informant and Base Informant

\begin{tabular}{|c|c|c|}
\hline No. & $\begin{array}{l}\text { Key } \\
\text { Informant }\end{array}$ & Base Informant \\
\hline 1. & $\begin{array}{l}\text { Daarut } \\
\text { Tauhid's } \\
\text { Santri Karya }\end{array}$ & $\begin{array}{ll}- & \text { Quality Control } \\
& \text { Team } \\
\text { - } & \text { Boarding School } \\
& \text { Boarding Leaders }\end{array}$ \\
\hline
\end{tabular}

Source: Analyzed by the Researchers 2019

To obtain the data, researchers used the instruments of observation, interviews and documentation. Meanwhile, to analyze the data, researchers use Data Reduction, Display Data, and Conclusion drawing Verification. From these three methods of data analyzing, it can be found that the data are interconnected and mutually sustainable, between one another. The researchers analyze the data before the process of data collection, during the process of data collection and after the process of data collection so that it can be analyzed thoroughly.

Besides, the data validity test that the researchers used is the triangulation, in order to find the most valid information.

\section{RESULTS AND DISCUSSION}

The findings and discussions found in in this research are:

\section{The Background of Implementing BRTT Program}

Daarut Tauhid's BRTT (Clean, Neat, Orderly, Organized) program began with the results of visiting some developed countries that is conducted by the leaders of this Islamic boarding schools. Then, they designed this program to be applied at Daarut Tauhid, with the hope that this boarding school could become a pioneer of doing good deeds.

For the boarding school's leaders, the BRTT program is part of syi'ar to the people who live around the environment in order to be able to instill BRTT principles to themselves in accordance to the teachings spread by Prophet Muhammad. Another hope is that, if many people around the school implemented this program properly, there 
will be a positive impact on the environment which is driven by the increasing number of people who actively care for the environment.

There are four essential components in BRTT program, which are clean, neat, orderly, and organized.

Basically, the concept of clean is interpreted differently to everyone. Some groups of people will say that environmental cleanliness does not only function as a means of ensuring the survival of living things; for them, there is another meaning that is more psychological, namely the actualization of attitudes and life behavior. Concern over environmental conditions encourages a person to actualize his attitude towards the environment to develop healthy behaviors, so that he can improve his lifestyle if he feels he has not paid enough attention to the cleanliness and health of the environment.

Neat and orderly are basically doing, using, then storing things according to their place. In the context of this research, orderly can be interpreted as the realization of a disciplined attitude. According to Djamarah (2008, p. 17), discipline is a form of orderly and organized implementation that can regulate the life arrangements of individuals and groups; meaning that they will tend to always fulfill the rules. Discipline arises from within the individual because of the urge to obey the order. Khalsa (2008, p. 19) argues that discipline itself is a part of an ongoing process of oneself's teaching or education.

Therefore, it can be concluded that organized is a condition in which a clean, neat and orderly attitude has been actualized by a certain group of individuals who live in a certain place. An organized environment will be inhabited by humans, animals and plants; all three of them will be able to survive as long as that order is implemented and preserved by them.

By linking the above theoretical concepts with the motives of Daarut Tauhid's BRTT program, it can be concluded that the background of implementing this program is the desire to make this Islamic boarding school as the pioneer of clean, neat, orderly, and organized behavior, which are implemented by its surrounding community.

\section{The Implementation of "BRTT" Program to the Santri Karya}

In the BRTT program, there are two program categories: internal and external. What distinguishes the two is the scope of each category: toilets, dormitories, and offices are the scope of internal programs, while the surrounding's environment of the Daarut Tauhid boarding school is the external categories. Implementation of the internal category of BRTT is carried out every day and is expected to become a habit that is instilled in the individuals. Meanwhile, the external BRTT category is held once a week with a predetermined schedule. A preliminary research conducted by Brian Suryo Basundoro on "An Overview of Ecological Intelligence of Surabaya Green And Clean Movers Citizens" resulting on the description of ecological intelligence found in the residents of Surabaya Green and Clean Movers. The activity involved in that program are including several aspects: cognitive, affection, and psychomotor which are supported and inhibited by some factors. The aspects shown in the study are in line with the BRTT concept, that there are three factors that influence discipline: selfconscious, family, and environmental habit. The obstacles that come from self-habits are lazy, undisciplined and irregular, so that the initial implementation of the BRTT program seems forced. But, it is later expected to become a habit that is inherent in the students themselves.

\section{Ecological Insight of Daarut Tauhid's Santri Karya}

There are seven aspects of the Daarut Tauhid's students ecological insight, which are: (1) understanding environmental issues and problems from the perspective of ecological balance and sustainability, for example by analyzing the number of floods that occur due to lack of concern for the environment by littering, (2) conducting BRTT starting from a rule, mandatory policies which gradually became a habit that is inherent in themselves, (3) a way to solve problems creatively and apply knowledge in a new situation (ecological context) that is the greening system for example in this DT replaced by DKM staff. Then a program is 
made by making miniature plants which are grown with plants as a small effort to keep the surrounding's environment green, absorbing pollution, providing comfort, beauty, and coolness, (4) oftenly assessing the impact and effects of human actions and technology on the environment, for example by comparing temperatures in the present and past (5) oftenly taking into account the long-term consequences in making a decision (environmental context), by using environmentally-friendly products, (6) knowing indicators of clean and healthy behavior, and (7) knowing ways to give attention, empathy, and care for others and other living things.

\section{CONCLUSION}

Based on the findings of the study, it can be concluded that the background of implementing the BRTT program is the desire to make Daarut Tauhid-Islamic Boarding School as a pioneer of clean, neat, orderly, and organized attitudes with the hope of being a role model for the people who live nearby in its surroundings.

The process of implementing the BRTT program is carried out in two categories: internal and external. The obstacles encountered in the implementation of the BRTT program are self-habits that are contrary to the BRTT program, for example lazy-like attitudes, undisciplined, irregular, which made so that the initial implementation of the BRTT program seems forced, which then becomes a habit even attached to the students themselves.

\section{ACKNOWLEDGEMENT}

To the Head of Social Science Education Study Program, Faculty of Social Science Education, and Universitas Pendidikan Indonesia for publishing this research paper on the journal of Social Science Study Education archieve.There are seven aspects of the Daarut Tauhid's students ecological insight, which are: (1) understanding environmental issues and problems from the perspective of ecological balance and sustainability, for example by analyzing the number of floods that occur due to lack of concern for the environment by littering, (2) conducting BRTT starting from a rule, mandatory policies which gradually became a habit that is inherent in themselves, (3) a way to solve problems creatively and apply knowledge in a new situation (ecological context) that is the greening system for example in this DT replaced by DKM staff. Then a program is made by making miniature plants which are grown with plants as a small effort to keep the surrounding's environment green, absorbing pollution, providing comfort, beauty, and coolness, (4) oftenly assessing the impact and effects of human actions and technology on the environment, for example by comparing temperatures in the present and past (5) oftenly taking into account the long-term consequences in making a decision (environmental context), by using environmentally-friendly products, (6) knowing indicators of clean and healthy behavior, and (7) knowing ways to give attention, empathy, and care for others and other living things.

\section{REFERENCES}

Azwar, Azrul. (1996). Menjaga Mutu Pelayanan Kesehatan. Jakarta: Pustaka Sinar Harapan

Capra, Fritjof. (1997). Titik Balik Peradaban:Sains, Masyarakat dan Kebangkitan

Kebudayaan. Alih Bahasa: M.Thoyibi. Yogyakarta: Bentang Budaya.

Departemen Kesehatan RI. UndangUndang Republik Indonesia Nomor 36

Tahun 2009 Tentang Kesehatan. Jakarta: Kementrian Kesehatan RI: 2009.

Djamarah. 2008. Guru dan Anak Didik. Jakarta: Penerbit Rineka Cipta.

Goleman, Daniel. 2009. Kecerdasan Emosional: Mengapa EI lebih penting daripada IQ. Jakarta : PT. Gramedia Pustaka Utama.

Khalsa, SiriNam S. 2008. Pengajaran Disiplin \& Harga Diri. Indonesia: Indeks. 
DEA MUTIARA, MAMAT RUHIMAT, YAKUB MALIK/ "BRTT” (Clean, Neat, Orderly, Organized) Program as a Pioneer of Daarut Tauhid Santri with Ecological Intelligence

Lembaga Pendidikan. Jakarta: Kencana.

Satria, Rizki. 2016. Pengembangan Topik Bencana Alam Dalam Pembelajaran Ips Untuk Meningkatkan Kecerdasan Ekologis Siswa Dalam Merawat Lingkungan Sekolah. International Jurnal Pedagogy of Social Studies. Vol 1 (2)

Septian, Yoga. 2016. Kecerdasan Ekologis Peserta Didik Sma Di Kota Bandung. International Jurnal Pedagogy of Social Studies. Vol 1 (2)
Setiawati, Tati. 2016. Peningkatan Kecerdasan Ekologis Peserta Didik Dalam Bertransportasi Hemat Bbm Melalui Pembelajaran Ips Kontekstual. International Jurnal Pedagogy of Social Studies. Vol 1 (2)Supriatna, Nana. (2016). Ecpedagogy. Membangun Kecerdasan Ekologis Dalam Pembelajaran IPS. Bandung: PT REMAJA ROSDAKARYA. 